\title{
ANÁLISE DA VIABILIDADE ECONÔMICA E ENERGÉTICA NA CONCENTRAÇÃO DA VINHAÇA: UM ESTUDO DE CASO EM USINA SUCROALCOOLEIRA NA CIDADE DE IVINHENA MS
}

\author{
Congresso Nacional Online de Empreendedorismo, 3ạ edição, de 06/12/2021 a 08/12/2021
} ISBN dos Anais: 978-65-81152-30-7

MASSON; Fabio Junior ${ }^{1}$, FILHO; Jose Perim ${ }^{2}$, SANTOS; Italo Coutinho dos ${ }^{3}$, SILVERIO; Adriano Serra ${ }^{4}$, SILVA; Raniéri Alves da 5

\section{RESUMO}

A atividade canavieira foi trazida para o Brasil durante o período colonial, e foi a primeira atividade agroindustrial desenvolvida no Brasil, sendo que, ainda no século XVI, o Brasil já alcançava o monopólio da produção de açúcar. O agroindustrial da cana-de-açúcar inclui significativa diversidade de agentes: produtos de cana-de-açúcar, usinas e/ou destilarias, distribuição dos produtos derivados e os diferentes consumidores, constituindo-se ainda este sistema em dois subsistemas principais: o açúcar e o álcool. O vinhoto também conhecido como vinhaça, tiborna ou restilo é o resíduo pastoso e malcheiroso que sobra após a destilação fracionada do caldo de cana-de-açúcar (garapa) fermentado para a obtenção do etanol (álcool etílico). Sendo muito volumosa a produção de resíduos do beneficiamento da cana de açúcar, tanto para o etanol quanto para o açúcar, a busca de tecnologias apropriadas para promover o gerenciamento, tratamento e aproveitamento dos mesmos constitui-se fator determinante para um desenvolvimento ambientalmente sustentável do complexo agroindustrial sucroalcooleiro. Quando os resíduos industriais não são bem gerenciados, aumentam sobremaneira os riscos de problemas ao meio ambiente, contudo, quando bem utilizados, diminuem significativamente os custos de produção, melhoram a imagem da empresa e as perspectivas de negócios e, principalmente, diminuem os riscos de danos ambientais. O estudo de caso emquestão teve como obletivo geral analisar da viabilidade econômica na concentração da vinhaça e como objetivos especifico comparar a viabilidade econômica da vinhaça concentrada em relação a in natura, além de descrever a rentabilidade na concentração da vinhaça. Demonstrar o funcionamento de um concentrador. O trabalho foi conduzido em uma indústria sucroalcoleira, no setor da destilaria localizada no município de Ivinhema-Mato Grosso do Sul. Foi feito análise e verificação das propriedades da vinhaça concentrada e seu rendimento econômico na indústria. A vinhaça e constituída basicamente de potássio, nitrogênio e uma grande porcentagem de matéria orgânica. Para fazer a aferição do brix de entrada, saída e a temperatura da vinha foi utilizado os seguintes materiais: Um sacarímetro, refratômetro digital para a leitura do brix da vinhaça, um béquer, uma peseta para fazer a limpeza do refratômetro e papel toalha para a limpeza. Como resultados pode-se destacar a importância da minimização da captação de água, onde leis ambientais cada vez mais rígidas tendem a diminuir outorgas de água de indústrias, que para isso, devem se condicionar a consumir menos água. 
Os resultados do trabalho demonstram que a implantação do aparelho se faz viável pela preservação ambiental e pela diminuição de custos nas áreas de pessoal e de transporte. Destaca-se ainda que concentração de vinhaça não alterou de forma significativa as propriedades físicas da água de reuso, entretanto, foi notória uma maior concentração de sólidos na vinhaça, com maior grau Brix e, consequentemente, maior geração de água para reuso. Pode-se afirmar que há viabilidade energética e econômica do reuso da água a partir de concentração da vinhaça por concentrador, podendo utilizá-la para fins menos nobres na indústria sucroalcooleira, reduzindo assim a captação nos corpos d'água.

PALAVRAS-CHAVE: sustentabilidade, vinhaça, gestão da qualidade, empreendimento, viabilidade econômica e energética 